\title{
Effect of gamma radiation on microbiological and oil properties of black cumin (Nigella sativa L.)
}

\author{
By Muhammet Arici ${ }^{1 *}$, Ferya Arslan Colak ${ }^{2}$ \\ and Ümit Gecgel ${ }^{1}$ \\ ${ }^{1}$ Department of Food Engineering, Faculty of Agriculture, Namik Kemal University, \\ 59030 Tekirdag, Turkey \\ ${ }^{2}$ Directorate of District-Cerkezkoy, Ministry of Agriculture and Rural Affair, \\ 59500 Çerkezköy-Tekirdag, Turkey \\ * Corresponding author, Tel: +90 282 2931442, Fax: +90 2822931480 , \\ E-mail: marici@tu.tzf.edu.tr
}

\section{RESUMEN}

\begin{abstract}
Efecto de la radiación gamma sobre la microbiología y las propiedaddes del aceite del comino negro (Nigella sativa L.)
\end{abstract}

Muestras de comino negro adquiridas en el mercado fueron irradiadas a dosis de 2.5 kGy, 6 kGy, 8 kGy y 10 kGy, respectivamente. Coincidiendo con el aumento en la dosis de irradiación, se incrementaron tanto la acidez libre, como el índice de peróxidos de las muestras, mientras que se redujeron en el aceite el índice de yodo, el índice de refracción y la resistencia a la oxidación medida por Rancimat. En la composición de ácidos grasos aumentaron los niveles de ácidos grasos trans, mientras que se redujeron los porcentajes de ácidos grasos insaturados. El recuento de microbios presentes en las muestras descendió, conforme aumentaba la dosis de irradiación aplicada. Se observó como los recuentos totales de bacterias, hongos y levaduras se redujeron hasta un límite indetectable.

PALABRAS-CLAVE: Comino negro - Composición en ácidos grasos - Irradiación - Nigella sativa - Propiedades físico-químicas y microbiológicas.

\section{SUMMARY}

Effect of gamma radiation on microbiological and oil properties of black cumin (Nigella sativa L.)

Black cumin samples obtained from the market have been irradiated under 2.5 kGy, 6 kGy, 8 kGy, and 10 kGy doses, respectively. Along with the increase in the dose of irradiation, both the free fatty acid and peroxide values of the samples increased, whereas oil contents, iodine numbers, refraction index and Rancimat values decreased. In the composition of fatty acids, while the percentages of unsaturated fatty acids decreased; trans fatty acid levels increased. Microbial count of the samples decreased as the dose of irradiation increased. It has been observed that total bacterial count as well as total count of yeast and mould reduced to the undetectable limit.

KEY-WORDS: Black cumin - Fatty acid composition Irradiation - Nigella sativa $L$ - Physicochemical and microbiological properties.

\section{INTRODUCTION}

The genus Nigella, belonging to the family Ranunculaceae, is represented by species of Mediterranean-western Asian origin. These are generally short-lived annuals, typical of disturbed soils or natural communities of semi-arid areas, with a dominance of therophytes. In the natural forms, flowers are bluish, with a variable number of sepals, and characterized by the presence of nectaries. The gynoecium is composed of a variable number of multi-ovule carpels, developing into a follicle after pollination, with single fruits partially connected to form a capsule-like structure. Seeds, of generally small size $(1-5 \mathrm{mg})$, dark grey or black in color and with corrugated integuments, represent the useful product. $N$. sativa is extensively used in traditional medicine, for healing various respiratory and gastro- intestinal diseases in all the Islamic countries, from Morocco to Pakistan (Riaz et al., 1996) and, locally, in southern Europe.

The composition and properties of this species have been fairly extensively investigated, and the results of the research have recently been reviewed (Riaz et al., 1996; Siddiqui and Sharma, 1996; Worthen et al., 1998). Whole seeds or their extracts have antidiabetic, antihistaminic, antihypertensive, anti-inflammatory, antimicrobial, antitumour, galactagogue and insect repellent effects. Most properties are mainly attributed to quinone constituents, of which thymoquinone is the most abundant. Quinonic alkaloids are likely to be involved in pharmaceutical properties as well. Another use of $N$. sativa seeds is as seasoning for foodstuffs like bread and pickles, especially widespread among Turkish people.

Nigella sativa (black cumin or black caraway) has been used much more extensively as compared with $N$. Damascena, both in medicinal and in food formulations (Babayan et al., 1978; Al-Jassir, 1992; Nergiz and Ötles, 1993; Takruri and Dameh, 1998).

Consequently $N$. sativa has been investigated more comprehensively. The seeds of $N$. sativa 
contain approximately $21 \%$ proteins and 30 to $40 \%$ oils, made up mainly of linoleic (58 to $65 \%$ ), oleic (22 to $24 \%$ ), and palmitic acid (13 to $20 \%$ ). Water constitutes about 4.4 to $5.6 \%$, ash 4.3 to $6.5 \%$, and essential oils 0.5 to $1.5 \%$ (Babayan et al., 1978; AlJassir, 1992; Nergiz and Ötles, 1993; Üstün, et al., 1990). The studies on the volatile oil of $N$. sativa volatile show that it possesses antimicrobial and pharmacological activities due to the presence of nigelone, thymoquinone, and thymohydroquinone (Babayan et al., 1978).

Under prevailing production and handling conditions, most spices, including black cumin and other vegetable seasonings contain a large number of microorganisms capable of causing spoilage or more often human diseases. Although used in small quantities, spices are a source of food contamination and there is a need, therefore, to eliminate the pathogenic or spoilage microflora in the spices. The current ban on the use of ethylene oxide fumigation in many countries because of its associated health hazards calls for an alternative method of decontamination (Akgul, 1989; Loaharanu, 1990; Hanafy and Hatem, 1991). Due to volatility and/or heat sensitivity of the delicate flavor and aroma components of spices and herbs, normal heat sterilization cannot be used without adversely affecting flavor and color (Sorenson, 1989).

The decontamination method which uses irradiation of high-energy electrons or gamma-rays has recently been receiving attention. In this study, the elimination of microorganisms by irradiation with 2.5, 6.0, 8.0 and 10.0 kGy gamma radiation doses and the effects of the applied doses on some physico-chemical properties and fatty acids composition of black cumin oil were examined.

\section{EXPERIMENTAL}

\subsection{Samples}

The samples of Nigella sativa L. (Black cumin) seeds related to family Ranunculaceae were purchased from a spices-grocery in Istanbul, Turkey.

\subsection{Irradiation of samples}

Black cumin seed samples (500 g) were sealed in polyethylene bags and irradiated at room temperature $\left(25^{\circ} \mathrm{C}\right)$ under ambient atmosphere in a Cobalt-60 Package Irradiator (JS 9600, MDS NORDION Int. Kanata, Ontario, Canada). The radiation doses selected for evaluation were 2.5, 6.0, 8.0 and $10.0 \mathrm{kGy}$ and delivered at a dose rate of $0.027 \mathrm{kG} / \mathrm{min}$. The absorbed dose was monitored by a Harwell Amber perspex dosimeter. A similar lot was kept as nonirradiated control sample.

\subsection{Oil Extraction}

Lipid extraction from the samples was carried out by hexane extraction under the operating conditions specified in IUPAC methods no. 1.121, and expressed as a percentage by mass of the product as received IUPAC (1987).

\subsection{Preparation of Fatty Acid Methyl Esters (FAME)}

FAME were prepared after alkaline hydrolysis, followed by methylation in methanol with $\mathrm{BF}_{3}$ as catalyst. The final concentration of the FAME was approximately $7 \mathrm{mg} / \mathrm{ml}$ in heptane (AOAC, 1990).

\subsubsection{Capillary Gas-Liquid Chromatography (GLC)}

Analyses of the FAME by capillary GLC were carried out on a Hewlett-Packard 6890 chromatograph, equipped with a flame-ionization detector (FID) on a split injector (chrompack, Middelburg, The Netherlands). A fused silica capillary column was used for the FAME analysis; $\mathrm{CP}^{\mathrm{TM}}$-Sil 88, $50 \mathrm{~m} \times 0.25 \mathrm{~mm}$ i.d., $0.2 \mu \mathrm{m}$ film; chrompack. The column was operated isothermally at $177^{\circ} \mathrm{C}$, injector and detector were kept at $250^{\circ} \mathrm{C}$. The carrier gas was helium with a flow rate of 1 $\mathrm{ml} / \mathrm{min}$.

\subsubsection{Stability to oxidation (automated Swift Test with Rancimat)}

Approximately $2.5 \mathrm{~g}$ of oil was heated for $10 \mathrm{~min}$ at $110{ }^{\circ} \mathrm{C}$ in the Rancimat heating block (679 Rancimat Instrument, Methrom-Herisau, Switzerland). The dry air feed and the collection vessel were then connected. The measurement of the conductivity curve was then started. The breaking point was equal to the induction time (hours) (Läubli et al., 1988). Free fatty acid contents, refraction index, peroxide and iodine values of oil samples extracted were determined in accordance with methods no. 2.201, 2.102, 2.501 and 2.205 of IUPAC (1987), respectively.

\subsubsection{Microbiological analyses}

Determination of the total viable counts, isolation of the moulds from control and irradiated black cumin seeds. Three grams in duplicate of each sample in sealed polyethylene bags were exposed to doses ranging from 2.5 to $10.0 \mathrm{kGy}$. Nonirradiated samples served as control. Each sample was suspended in $27 \mathrm{ml}$ normal sterile saline solution containing a few drops of Tween 20 and decimal dilutions of the suspensions were made.

\subsubsection{Viable bacterial count}

To obtain the viable bacterial count, $1 \mathrm{ml}$ of the diluted samples was transferred into duplicate sterile plates of PCA and incubated at $30^{\circ} \mathrm{C}$ for $72 \mathrm{~h}$ and the number of colony-forming units (cfu) counted (Baumgart, 1993). 


\subsubsection{Total fungi count}

The number of fungal colony-forming units was determined by serially diluting the preparations and plating duplicate samples onto potato dextrose agar. The plates were incubated for 5 days at $25^{\circ} \mathrm{C}$, the colonies were counted and the data were expressed as the number of colony-forming units (cfu) per gram (Baumgart, 1993).

\subsection{Statistical analysis}

The data obtained from three replications were analyzed by ANOVA using the SPSS statistical package program, and differences among the means were compared using the Duncan's multiple range test.

\section{RESULTS AND DISCUSSION}

Black cumin seed samples that have been gamma irradiated at 2, 6, 8 and $10 \mathrm{kGy}$, and the control sample were examined to determine their oil and free fatty acid contents, peroxide and iodine values, refraction index, rancimat values, fatty acid compositions and microbiological properties. Table 1,2 and 3 present the results.

The oil content of non-irradiated and irradiated with $10 \mathrm{kGy}$ black cumin seeds were $36.1 \%$ and $31.6 \%$, respectively. It was also found that there is an inverse relationship between oil content and irradiation dose, namely, if irradiation dose increases, oil content decreases. The effect of irradiation exposure on oil content of black cumin seed samples was found statistically important at the level of $p<0.05$.

The free fatty acid level was $0.61 \%$ before irradiation and increased to $1.72 \%$ after the $10 \mathrm{kGy}$ irradiation. It was found that the effect of irradiation exposure on the free fatty acid of samples was statistically important $(p<0.01)$. According to the research result, if the dose level of irradiation increases, free fatty acid value increases proportionally. Wen et al., (2006) found no significant change in $\mathrm{pH}$ and acidity following 4, 8 and 14 kGy gamma irradiation in lycium fruit.

The lipid oxidation was attributed to the combination of free radicals with $\mathrm{O}_{2}$ to form hydroperoxides. In this study, peroxide values were also increased in irradiated samples. A positive correlation between the irradiation dose and peroxide value of the samples was found and 2.2 meqO $\mathrm{O}_{2} / \mathrm{kg}$ identified in the oil whose seeds were not exposed to irradiation. Regarding irradiation exposure, the peroxide value in the oil was gradually decreased to $3.7 \mathrm{meqO}_{2} / \mathrm{kg}$, the most value, was identified in the oil sample irradiated with 10 kGy. It was found that the effect of irradiation exposure on the peroxide value of black cumin seed samples was statistically important $(p<0.01)$. Oxidative change caused by irradiation is the same as in the reaction of unexposed seeds. Radicals and induced molecules form as the result of irradiation exposure. After irradiation exposure, these free radicals can react with $\mathrm{O}_{2}$ in the long run and cause the formation of hydroperoxides which create alcohols, aldehides, aldehide esters and hydrocarbons (Pearson et al., 1983). Hampson et al., (1996) reported that peroxide and iodine values of the meat lipids exposed to low irradiation dose $(<10$ kGy) showed no significant changes.

The effects of various levels of gamma irradiation on stability in rancimat values are shown in Table 1. A negative correlation was found between rancimat value and irradiation doses. According to this data, at the beginning, while the oil of the sample which is not exposed to irradiation had a resistance time of 7.72 hours, the highest value; it was found that related to the irradiation doses, induction time of the sample's oils decreased and the lowest value of the oil of the sample of $10 \mathrm{kGy}$ was recorded as 0.62 hours. It was found that the effect of irradiation exposure on the rancimat rate of black cumin seed samples was statistically significant $(p<0.01)$.

The effect of various levels of gamma irradiation on iodine number and refraction index is shown in Table 1. The negative correlation between iodine number and refraction index was also shown in

Table 1

The effect of irradiation on thephysicochemical properties of black cumin seed oil.

\begin{tabular}{|c|c|c|c|c|c|c|}
\hline $\begin{array}{l}\text { Radiation } \\
\text { Doses } \\
\text { (kGy) }\end{array}$ & Oil (\%) & $\begin{array}{c}\text { Acidity } \\
\text { (FFA; oleic } \\
\text { acid \%) }\end{array}$ & $\begin{array}{c}\text { Peroxide } \\
\text { values } \\
\left(\mathrm{meqO}_{2} / \mathrm{kg}\right)\end{array}$ & $\begin{array}{c}\text { Stability in } \\
\text { Rancimat } \\
\text { (h) }\end{array}$ & $\begin{array}{l}\text { lodine } \\
\text { number }\end{array}$ & $\begin{array}{c}\text { Refraction } \\
\text { index } \\
\left(25^{\circ} \mathrm{C}\right)\end{array}$ \\
\hline 0 & $36.1 a$ & $0,61 a$ & $2.2 \mathrm{a}$ & $7.72 a$ & 121.9a & 1.4603 \\
\hline 2.5 & $35.1 \mathrm{a}$ & $0,82 a$ & $2.3 \mathrm{a}$ & $5.43 a$ & $118.6 b$ & 1.4602 \\
\hline 6.0 & $34.5 \mathrm{ab}$ & $1,15 b$ & $3.4 a$ & $3.60 \mathrm{~b}$ & $118.2 b$ & 1.4594 \\
\hline 8.0 & $32.7 \mathrm{bc}$ & $1,54 \mathrm{c}$ & $3.5 b$ & $1.92 \mathrm{c}$ & $116.2 \mathrm{bc}$ & 1.4590 \\
\hline 10.0 & $31.6 c$ & $1,72 \mathrm{c}$ & $3.7 \mathrm{~b}$ & $0.62 \mathrm{c}$ & $114 c$ & 1.4570 \\
\hline$p$ level & * & ** & $* *$ & $\star \star$ & $\star *$ & NS \\
\hline
\end{tabular}

Each value is an average of three determinations

abc Mean values in the same column not sharing a superscript are significantly different

NS: not significant

* Significant at $p<0.05$

** Significant at $p<0.01$ 
irradiation exposure rates; while the highest values were acquired from the oil of the sample which is not exposed to irradiation; and relating to the irradiation dosages this values decreased, and finally the lowest values recorded in the sample was treated with $10 \mathrm{kGy}$ irradiation (Table 1). In other words, as a result of irradiation exposure, saturated oils increased and unsaturated oils decreased. It was found that the effect of irradiation exposure on the iodine number of black cumin seed samples was statistically significant $(p<0.01)$, the effect of irradiation exposure on the refraction index was found insignificant. Hampson et al. (1996) have found that peroxide, which is formed after irradiation exposure, breaks the dual links of oxygen, hydroperoxide and hydroxide free radicals and removes the dual link feature. Researchers say that as a result of high dosage irradiation exposure, dual link refractions would increase and as the sign of this condition iodine number would decrease.

Fatty acid composition values, which belong to the oil of irradiated black cumin seed samples, are shown in Table 2. Compositions and differences related with irradiation exposure doses; palmitic, stearic, oleic cis and trans, linoleic cis and trans fatty acids and total trans, total saturated and total unsaturated fatty acids were statistically analyzed. Other fatty acids were not analyzed since they do not indicate a significant difference regarding the irradiation exposure dose and proportional side.

As the result of statistical evaluation, significant effects of irradiation exposure doses on fatty acid composition of black cumin seed oils were determined; stearic acid $(\mathrm{p}<0.05)$, oleic acid cis and trans $(p<0.01)$, linoleic acid trans $(p<0.01)$ and total trans $(p<0.01)$. The effects of irradiation on other fatty acids (palmitic, linoleic cis, total saturated and total unsaturated) were determined as nonsignificant.

It was observed that, parallel to the increases in irradiation doses, there is also an increase in total saturated fatty acid rates (15.43\% - $16.82 \%)$, and there is a decrease in total unsaturated fatty acid rates $(84.57 \%$ - $83.18 \%$ ) (Table 2$)$. Additionally, a considerable increase was observed in trans fatty acids; the initial value $0.37 \%$ was increased to $0.61 \%$ at the final $10 \mathrm{kGy}$ irradiation exposure. It was estimated that, the reason for the increase in trans fatty acids and the decrease in unsaturated fatty acids during the irradiation exposure was because of a molecular structure change in fatty acids, the breaking of dual links and radicals and trans fatty acids turning to free condition. Consequently, the increase in trans fatty acids in black cumin seed oil is determined as a considerable factor that must be emphasized during irradiation exposure processes.

The number of aerobic plate and fungal counts decreased with the increase of irradiation doses. Irradiation reduced the bacterial population in a dose-dependent manner. A dose of $2.5 \mathrm{kGy}$ reduced the total viable bacterial load by less than 1 log per cycle while a dose of $8.0 \mathrm{kGy}$ reduced the total viable bacterial count by more than 1 log per cycle (Table 3). Irradiation with doses of 6.0, 8.0 and $10.0 \mathrm{kGy}$ resulted in a decrease in the total viable

Table 2

The effect of irradiation on thefatty acid composition of black cumin seed oil.

\begin{tabular}{|c|c|c|c|c|c|c|}
\hline \multirow{2}{*}{ Fatty Acids (\%) } & \multicolumn{5}{|c|}{ Irradiation doses (kGy) } & \multirow{2}{*}{$p$ level } \\
\hline & 0 & 2,5 & 6 & 8 & 10 & \\
\hline Miristic $C_{14: 0}$ & 0.18 & 0.18 & 0.20 & 0.22 & 0.22 & \\
\hline Palmitic $\mathrm{C}_{16: 0}$ & 11.56 & 12.54 & 12.03 & 11.98 & 12.36 & NS \\
\hline Palmitoleic $\mathrm{C}_{16: 1}$ & 0.20 & 0.22 & 0.23 & 0.22 & 0.23 & \\
\hline Margaric $\mathrm{C}_{17: 0}$ & 0.07 & 0.07 & 0.08 & 0.10 & 0.12 & \\
\hline Heptadesenoic $C_{17: 1}$ & 0.05 & 0.06 & 0.05 & 0.05 & 0.06 & \\
\hline Stearic $C_{18: 0}$ & $3.35^{\mathrm{a}}$ & $3.37^{a}$ & $3.87^{a}$ & $3.83^{b}$ & $3.75^{\mathrm{b}}$ & * \\
\hline Oleic $\mathrm{C}_{18: 1}$ cis & $24.91^{a}$ & $24.11^{\mathrm{b}}$ & $24.10^{b}$ & $24.10^{\mathrm{b}}$ & $23.98^{b}$ & ** \\
\hline Oleic $\mathrm{C}_{18: 1}$ trans & $0.02^{\mathrm{a}}$ & $0.02^{\mathrm{a}}$ & $0.03^{b}$ & $0.06^{\mathrm{b}}$ & $0.08^{b}$ & $\star \star$ \\
\hline Linoleic $\mathrm{C}_{18: 2}$ cis & 59.02 & 58.74 & 58.62 & 58.56 & 58.20 & NS \\
\hline Linoleic $\mathrm{C}_{18: 2}$ trans & $0.35^{a}$ & $0.36^{b}$ & $0.40^{\mathrm{bc}}$ & $0.45^{c}$ & $0.53^{c}$ & $\star *$ \\
\hline Arachidic $\mathrm{C}_{20: 0}$ & 0.24 & 0.24 & 0.26 & 0.26 & 0.28 & \\
\hline Behenic $\mathrm{C}_{22: 0}$ & 0.03 & 0.05 & 0.07 & 0.09 & 0.09 & \\
\hline Dokosadienoic $\mathrm{C}_{22: 2}$ & 0.02 & 0.04 & 0.06 & 0.08 & 0.10 & \\
\hline Total trans & $0.37^{a}$ & $0.38^{b}$ & $0.43^{b c}$ & $0.51^{c}$ & $0.61^{c}$ & $\star \star *$ \\
\hline Total saturated & 15.43 & 16.45 & 16.51 & 16.48 & 16.82 & NS \\
\hline Total monounsaturated & 25.18 & 24.41 & 24.41 & 24.43 & 24.35 & \\
\hline Total polyunsaturated & 59.39 & 59.14 & 59.08 & 59.09 & 58.83 & \\
\hline Total unsaturated & 84.57 & 83.55 & 83.49 & 83.52 & 83.18 & NS \\
\hline Total unsaturated / Total saturated & 5.48 & 5.07 & 5.05 & 5.06 & 4.94 & \\
\hline
\end{tabular}

Each value is an average of three determinations

${ }^{a b c}$ Mean values in the same column not sharing a superscript are significantly different

$N S$ : not significant

* Significant at $p<0.05$

** Significant at $p<0.01$ 
Table 3

The effect of irradiation on some microbiological properties of black cumin seed ${ }^{*}$.

\begin{tabular}{ccc}
\hline $\begin{array}{c}\text { Irradiation } \\
\text { doses } \\
\text { (kGy) }\end{array}$ & $\begin{array}{c}\text { Count of viable } \\
\text { bacteria } \\
\text { (log cfu/g) }\end{array}$ & $\begin{array}{c}\text { Count of total } \\
\text { fungi } \\
\text { (log cfu/g) }\end{array}$ \\
\hline 0 & $3.49 \pm 0.18^{\star \star}$ & $3.55 \pm 0.17$ \\
2.5 & $2.96 \pm 0.05$ & $3.15 \pm 0.21$ \\
6.0 & $2.84 \pm 0.10$ & $2.15 \pm 0.21$ \\
8.0 & $2.47 \pm 0.31$ & $1.26 \pm 0.13$ \\
10.0 & $0.00 \pm 0.00$ & $0.00 \pm 0.00$ \\
\hline
\end{tabular}

* Each value is an average of three determinations ** SD

fungal count by 1, 2 and 3 log cycles, respectively. Moulds are known to be relatively sensitive to irradiation (Wills, 1983); hence, a dose of 10 kGy completely eliminated the fungal population.

In conclusion, irradiation of food can effectively reduce or eliminate microorganisms. On the other hand, irradiation treatment brings about some biochemical changes. The trans fatty acid contents of the black cumin samples increased with more irradiation dosages.

\section{ACKNOWLEDGEMENT}

The authors gratefully acknowledge GammaPak Sterilizasyon Sanayi ve Ticaret A.S. (Cerkezkoy - Tekirdag,Turkey) for the irradiation applications in this work.

\section{BIBLIOGRAPHY}

Akgul A. 1989. Antimicrobial activity of black cumin (Nigella sativa L.) essential oil. Gazi Universitesi Eczacilik Fakultesi Dergisi 6, 63-68.

Al-Jassir MS. 1992. Chemical composition and microflora of black cumin (Nigella sativa L.) seeds growing in Saudi Arabia. Food Chemistry 45, 239-242.

AOAC 1990. Official Methods of Analysis of the Association of Official Analytical Chemists, 15th ed AOAC, Virginia.

Babayan VK, Koottungal D, Halaby GA. 1978. Proximate analysis, fatty acid and amino acid composition of Nigella. sativa $L$ seeds. Journal of Food Science 43, 1314-1319.
Baumgart J. 1993. Mikrobiologische Untersuchung von Lebensmitteln, Behr's Verlag, Hamburg.

Hampson JW, Fox JB, Lakritz L, Thayer DW. 1996. Effect of low dose gamma radiation on lipids in five different meats. Meat Science 42, 271-276.

Hanafy MSM, Hatem ME. 1991. Studies on the antimicrobial activity of Nigella sativa seed (black cumin). Journal of Ethnopharmacology 34, 275-278.

IUPAC 1987. Standard Methods for the Analysis of Oils, Fats and Derivatives International Union Pure and Applied Chemistry Division Commission on Oils, Fats and Derivatives, $7^{\text {th }}$ ed, Blackwell Jevent Publishers, Oxford.

Läubli MV, Bruttel PA, Schalch E. 1988. A modern method of determining the oxidative stability of fats and oils. Food Marketing and Technology March 16-18.

Loaharanu P. 1990. Role of irradiation to facilitate international trade in pepper. $15^{\text {th }}$ Peppertech and $2^{\text {nd }}$ Pepperxim meet Convened by the Int Pepper Community (IPC) London, 21-25 May.

Nergiz C, Ötles S. 1993. Chemical composition of Nigella sativa L. seeds. Food Chemistry 48, 259-261.

Pearson AM, Gray JI, Wolzak AM, Horenstein NA. 1983. Safety implications of oxidized lipids in muscle foods. Food Technology July, 121-129.

Riaz M, Syed M, Chaudhary FM. 1996. Chemistry of the medicinal plants of the genus Nigella. Hamdard Medicus 39, 40-45.

Siddiqui AA, Sharma PKR. 1996. Clinical importance of. Nigella sativa L. a review. Hamdard Medicus 39, 38-42.

Sorenson S. 1989. Heat sterilization of spices. First meet. Pepper Exporters Importers Traders Grinders organized by the Int Pepper community, Bali, Indonesia, 1-2 June.

Takruri HRH, Dameh MAF. 1998. Study of the nutritional value of black cumin seeds (Nigella sativa L.). Journal of the Science of Food and Agriculture 76, 404-410.

Üstün G, Kent L, Çekin N, Civelekoglu H. 1990. Investigation of the technological properties of Nigella sativa (Black Cumin) seed oil. J.A.O.C.S. 67, 958-960.

Wen HW, Chung HP, Chou FI, Lin I, Hsieh PC. 2006. Effect of gamma irradiation on microbial decontamination, and chemical and sensory characteristic of lycium fruit. Radiation Physics and Chemistry 75, 596-603.

Wills PA. 1983. Radiation microbiology in food preservation. In: Proc. Natl. Symp. Ionizing Energy Treatment of Foods, Sydney, Australia, 5-6 Oct 1982, pp 19-26.

Worthen DR, Ghosheh OA, Crooks PA. 1998. The in vitro anti-tumor activity of some crude and purified components of blackseed, Nigella sativa L. Anticancer Research 18, 1527-1532.

Recibido: 11/10/06 Aceptado: 13/05/07 